Editors' Note: The letters by Khoo and Armstrong agree that future studies and guidelines should address the periprocedural management of novel anticoagulant agents (e.g., direct thrombin inhibitors and factor $\mathrm{Xa}$ inhibitors) in patients with ischemic cerebrovascular disease. Commenting on the article by Mehndiratta et al. on the challenges of stroke in India, Sharma stresses the importance of including emergency medical services in stroke management in India. Furthermore, Sethi mentions the negative lifestyle changes that young Indians are undergoing and suggests improving national health policies to further prevent and treat stroke.

-Chafic Karam, MD, and Robert C. Griggs, $M D$

SUMMARY OF EVIDENCE-BASED GUIDELINE: PERIPROCEDURAL MANAGEMENT OF ANTITHROMBOTIC MEDICATIONS IN PATIENTS WITH ISCHEMIC CEREBROVASCULAR DISEASE: REPORT OF THE GUIDELINE DEVELOPMENT SUBCOMMITTEE OF THE AMERICAN ACADEMY OF NEUROLOGY

Kah Fang Khoo, Bayan Lepas, Malaysia: This guideline is especially helpful in my daily management of patients. ${ }^{1}$ Patients taking warfarin come to my clinic to obtain referrals for dental extraction because most dental surgeons in Malaysia refuse to perform dental procedures without clearance. I agree with the continuation of warfarin during dental procedures but certain precautions should be taken. Oral surgery may be completed safely at international normalized ratios (INRs) of $1.5-2.5^{2}$ and up to INR 4 for a small procedure. ${ }^{3}$ The INR should be checked prior to surgery. For simple extractions, bleeding should be controlled by minimizing surgery to only one site, and postoperative packs or firm sutures should cover the wound. Local anesthetic should be given cautiously to avoid venipunctures. ${ }^{4} \mathrm{I}$ hope a future guideline will address novel anticoagulant therapy for use during dental procedures.

Author response: Melissa J. Armstrong, Baltimore, MD; José Biller, Chicago, IL; Larry B. Goldstein, Durham, NC; Michael Schneck, Maywood, IL; Steven R. Messé, Philadelphia, PA: We appreciate Dr. Khoo's comments and are pleased that the guideline will be useful in daily patient management. ${ }^{1}$ We agree that it is reasonable to consider the degree of anticoagulation when continuing warfarin periprocedurally to reduce bleeding risks. However, because of differences in approach between studies, we were unable to make recommendations regarding target INRs when anticoagulation is continued or optimal timing when agents are discontinued. We did not find studies formally investigating INR or timing strategies. Review articles and consensus statements such as those referenced propose approaches that are reasonable for clinicians to consider when making these decisions, but high-quality studies evaluating the best approach are not available. Studies evaluating periprocedural management strategies for newer anticoagulants such as oral direct thrombin inhibitors and factor Xa inhibitors will be important for informing future guidelines with regard to the perioperative management of stroke patients.

(C) 2013 American Academy of Neurology

1. Armstrong MJ, Gronseth G, Anderson DC, et al. Summary of evidence-based guideline: periprocedural management of antithrombotic medications in patients with ischemic cerebrovascular disease: report of the Guideline Development Subcommittee of the American Academy of Neurology. Neurology 2013;80:2065-2069.

2. Little JW, Falace DA, Miller CS, et al. Dental Management of Medically Compromised Patient, 5th ed. St. Louis: Mosby; 1997.

3. Devani P, Lavary KM, Howell CJ. Dental extraction in patient on warfarin: is alteration of anticoagulant necessary? Br J Oral Maxillofac Surg 1998;36:107-111.

4. Savage N. Managing dental patients receiving warfarin therapy. Aust Prescr 2002;25:69.

\section{MEETING THE CHALLENGES OF STROKE IN INDIA}

Mohit Sharma, Brooklyn, NY: I agree with Mehndiratta et al., who outlined concerns about stroke in India. ${ }^{1}$ India needs to invest more in stroke research and to develop adequate stroke infrastructure for its 1.2 billion citizens. Progress is being made by the Indian Stroke Association (ISA) and the recent launch of the Indian Stroke Registry. However, the authors missed the importance of emergency medical services (EMS). The American Heart Association/American Stroke Association guidelines for the management of adults with ischemic stroke include the role of EMS in the stroke chain of survival. ${ }^{2}$ Early stroke detection, EMS dispatch, 


\section{Neurology}

Summary of evidence-based guideline: Periprocedural management of antithrombotic medications in patients with ischemic cerebrovascular disease: Report of the Guideline Development Subcommittee of the American Academy of Neurology

Kah Fang Khoo, Melissa J. Armstrong, Bayan Lepas, et al. Neurology 2014;82;95

DOI 10.1212/01.NEUROLOGY.0000437348.92583.18

This information is current as of December 30, 2013

Updated Information \& Services

References

Permissions \& Licensing

Reprints including high resolution figures, can be found at: http://n.neurology.org/content/82/1/95.1.full

This article cites 3 articles, 1 of which you can access for free at: http://n.neurology.org/content/82/1/95.1.full\#ref-list-1

Information about reproducing this article in parts (figures,tables) or in its entirety can be found online at:

http://www.neurology.org/about/about_the_journal\#permissions

Information about ordering reprints can be found online: http://n.neurology.org/subscribers/advertise

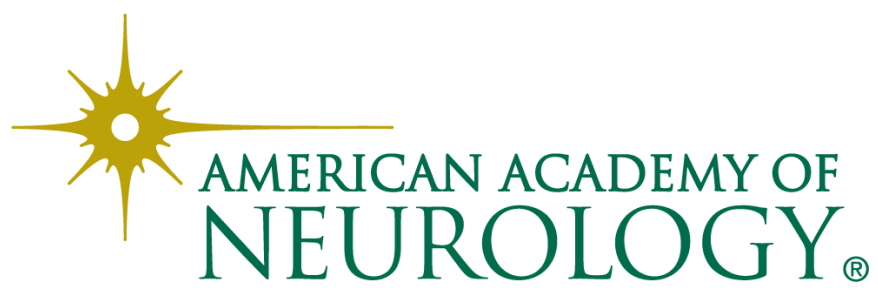

